\title{
"Money Rules the World, but Who Rules the Money?" Antisemitism in post-Holocaust Conspiracy Ideologies
}

Current conspiracy narratives initially appear to exhibit no connection with antisemitism. "1\%," "Vaccination-lie," "Chemtrails," or the "Flat Earth Conspiracy" do not overtly invoke the "Jewish World Conspiracy." This study focusses on the relation between antisemitism and conspiracy ideologies under the premise of "detour-communication." The first part demonstrates that antisemitism and conspiracy ideologies share common structures and functions, which impede a clear distinction. This distinction is further complicated by "detour-communication": An implicit way to express antisemitic statements via codes and ciphers after the Holocaust since overt and explicit expressions of antisemitism were tabooed in Western states. The second part focuses on the historical dynamics of the "Jewish World Conspiracy" myth from Christian medieval allegations to those of The Protocols of the Elders of Zion. In a qualitative analysis of 200 posts from German conspiracy-ideological Facebook pages, this study demonstrates the ways in which antisemitic codes are used to direct non-antisemitic expressions to the myth of the "Jewish World Conspiracy." Therefore, this study illustrates that elements of the Protocols are still being used in conspiracy-ideological communications on the internet.

\section{Introduction}

Since the Islamist terror attacks of September 11, 2001, conspiracy ideologies are clearly discernable. At that time, the available technological possibilities of the internet, regarding production and distribution of information and propaganda, played right into the hands of their dissemination. Since then conspiracy ideologies have increasingly penetrated public discourse and are even disseminated by heads of states, themselves, such as Donald Trump in the USA or Viktor Orbán in Hungary. ${ }^{1}$ The latter case especially shows that these statements are accompanied by an antisemitic connotation. ${ }^{2}$ This is no coincidence.

1 See, e.g., R. Cohen, “Trump Clings to Conspiracy Theories-and Strengthens the Case for his Removal,” The Washington Post, November 29, 2017, https://www.washingtonpost.com/blogs/

Ә OpenAccess. ( 2021 Armin Lange, Kerstin Mayerhofer, Dina Porat, Lawrence H. Schiffmann, published by De Gruyter. (cc))BY-NC-ND This work is licensed under the Creative Commons Attribution-NonCommercialNoDerivatives 4.0 International License. https://doi.org/10.1515/9783110671964-005 
This essay considers the question of what kind of relation exists between antisemitism and modern conspiracy ideologies. To this end, on the basis of theoretical reflection, the study points out that antisemitism and conspiracy ideologies command the same structures and functions. Thus, they cannot simply be separated from one another. The fact that since the Holocaust this relation is concealed via the communicative strategy of detour-communication ("Umwegkommunikation") in which antisemitic attitudes are no longer expressed explicitly but instead implicitly, by means of codes and ciphers, additionally complicates this matter.

The second part of this essay traces the development history of the myth of "Jewish World Conspiracy" in order to illustrate that Jews assume a special role regarding the construction of enemy images. Associated with the anti-Christ during Christian medieval times, they became the epitome of enlightenment and modernity since the French Revolution. At the beginning of the twentieth century, the myth was eventually condensed into the plagiarism of The Protocols of the Elders of Zion by actors who, as yet, have not been unequivocally identified. This document constitutes a central element for both antisemitism and modern conspiracy ideologies that are still being disseminated, despite-or maybe even because of-its early refutation. ${ }^{3}$

The third part traces the ways in which the myth of the "Jewish World Conspiracy" is disseminated on the internet via the Protocols and under consideration of detour-communication by means of a short qualitative study. For this purpose, 200 posts on Facebook were analyzed that were published by the ten largest German-language conspiracy-ideological pages on the platform.

\section{Antisemitism and Conspiracy Ideologies}

To analyze the connection between antisemitism and conspiracy ideologies, first of all, the field of research and the central terms need to be isolated. The analysis is bound to the time period after the atrocious crime against humanity, the Hol-

post-partisan/wp/2017/11/29/trump-clings-to-conspiracy-theories-and-strengthens-the-case-forhis-removal/.

2 See L. Bayer and L. Cohler-Esses, "Evil Soros: Dog Whistling Anti-Semitism in Viktor Orbán’s Hungary,” Forward, May 30, 2017, https://forward.com/news/world/373162/evil-soros-dog-whis tling-anti-semitism-in-viktor-orbans-hungary/.

3 Scans of original editions of the Protocols besides antisemitic-conspiracy-ideological reinterpretations and commentaries, for example, can be found in the digital library of the project Internet Archive, archive.org. 
ocaust, as new manifestations of antisemitism formed in its succession which need to be regarded with special consideration. Antisemitism is understood, following Lars Rensmann,

as a special, modern, politically and culturally situated form of stereotype-formation, as also [...] an ensemble of prejudices, clichés, fixed collective images, binary codes and categorical attributions, and discriminating practices against Jews, which can be condensed into a political ideology and into a worldview. Although criteria for capturing these can be systematically accounted for, antisemitic patterns of prejudice and ideologemes, thus, in the ideology-historical process do not manifest themselves in a rigid and identical manner, but instead, they are to be interpreted as dependent of the political constellation and the political and cultural structure. In the democratic context, they often appear in coded, indirect, and symbolic forms, which aim toward the winking "knowledge" and approval of the addressed electorate. ${ }^{4}$

To define the term conspiracy ideology, I refer to the important preliminary works of Armin Pfahl-Traughber. In 2002 he criticized the analytical unsuitability of the term "conspiracy theory" and countered it with the following four terms as alternative. Conspiracies, whose existence he does not deny, are the starting point. They are understood as a secret agreement of a small group, with a relatively short-term horizon for planning to achieve a certain objective. The existence of conspiracies then legitimates the conspiracy hypothesis, hence the assumption that a certain event is the result of a conspiracy. The conspiracy ideology, on the other hand, is distinguished by Pfahl-Traughber as a hypothesis, immunized against criticism, in which the conspiracy has become a dogmatic basic premise. Whereas a conspiracy ideology is still bound to real groups, like for example Mossad, CIA, and Freemasons, the conspiracy myth, as an ideal typically distinguished variant of the conspiracy ideology, is directed against fictional, mythical groups, for example, the "elders of Zion," the Illuminati, or aliens. ${ }^{5}$ In accordance with this definition, the following analysis is applied to the relation between antisemitism and conspiracy ideologies and myths.

4 L. Rensmann, Demokratie und Judenbild: Antisemitismus in der politischen Kultur der Bundesrepublik Deutschland (Wiesbaden: VS Verlag für Sozialwissenschaften, 2005), 20.

5 Cf. A. Pfahl-Traughber, “'Bausteine’ zu einer Theorie über 'Verschwörungstheorien': Definitionen, Erscheinungsformen, Funktionen und Ursachen," in Verschwörungstheorien: Theorie-Geschichte-Wirkung, ed. H. Reinalter (Innsbruck: Studien-Verlag, 2002), $31 \mathrm{f}$. 


\section{Structure, Function, and Detour-Communication}

In her article "Verschwörungstheorien" ("Conspiracy Theories") of the Handbuch des Antisemitismus (Handbook of Antisemitism), Juliane Wetzel describes the relation between antisemitism and conspiracy ideologies as follows:

Conspiracy theories do not always, but often have an antisemitic connotation, because Jews have become a classical scapegoat throughout past centuries, and there exists a manifold repertoire of stereotypes from which reasons can be construed all too easily, for events and developments that are, in fact, difficult to be explained. ${ }^{6}$

Wetzel distinguishes between non-antisemitically connotated "conspiracy theories" and those "often" encountered antisemitically connotated ones. In a historical-functional manner, she regards the scapegoat-function of Jews and the existent anti-Jewish stereotypes which possess an explanatory function for those facts that are hard to explain as the reason for the correlation. Furthermore, in his analysis of the current conspiracy-campaign of German right-wing extremism, Samuel Salzborn establishes that "the motive of conspiracy [...] is historically and systematically antisemitic." In accordance with these determinations, the relation between antisemitism and conspiracy ideology can be analyzed from two perspectives, that of antisemitism research and that of the studies regarding conspiracy ideologies.

More recent antisemitism research, regarding the relation between antisemitism and conspiracy ideologies, refers to Thomas Haury's studies which state a structural correlation. ${ }^{8}$ As the basis of his analysis of left-wing antisemitism, Haury describes three structural principles of the antisemitic worldview: Personification, Manichaeism, as well as the construction of identitary collectives. With-

6 J. Wetzel, "Verschwörungstheorien," in Begriffe, Theorien, Ideologien, vol. 3 of Handbuch des Antisemitismus: Judenfeindschaft in Geschichte und Gegenwart, ed. W. Benz (Berlin: De Gruyter Saur, 2010), 335.

7 S. Salzborn, “Vom rechten Wahn: 'Lügenpresse,' 'USrael,' ‘Die da oben’ und 'Überfremdung', in Stolz und Vorurteile, ed. M. Bauer, K. Malowitz, and S. Mörchen, Mittelweg 36: Zeitschrift des Hamburger Instituts für Sozialforschung 6 (2016/2017): 83. See also T. D. Uhlig, "Abgründe der Aufklärung: Über Verschwörungstheorien als antisemitisches Zerrbild der Ideologiekritik,” in Populismus, Paranoia, Pogrom: Affekterbschaften des Nationalsozialismus, ed. K. Grünberg, W. Leuschner, and Initiative 9. November (Frankfurt/Main: Brandes \& Apsel, 2017), 156.

8 See, e.g., S. Munnes, N. Lege, and C. Harsch, "Zum Antisemitismus in der neuen Friedensbewegung: Eine Weltanschauungsanalyse der ersten bundesweiten Mahnwachen für den Frieden," in Jahrbuch für Antisemitismusforschung 25, ed. S. Schüler-Springorum (Berlin: Metropol-Verlag, 2016), $222 \mathrm{f}$. 
in the structural principle of Personification, Jews are understood as the epitome of abstract and mediated processes of modern societies and conceived as the originators of these. These images are united in the myth of the "Jewish World Conspiracy"-the conspiracy theory is, therefore, part of the personification. In turn, the second structural principle of Manichaeism is characterized by a radical dualistic division of the world into Good and Evil, the identification of the enemy as something life-threateningly Evil and an eschatological main feature. Identitary collectives form the last structural principle of antisemitism, which can only analytically be distinguished from Manichaeism. Within this structural principle, it is not individuals but only collectives who are granted a subject status, which are determined by a specific, unalterable-therefore identitary-being. ${ }^{9}$

The analysis of the structural principles of conspiracy ideologies requires further analytical sharpening of the term. Kurt Lenk's historical-genetical typology extends the Pfahl-Traughberian understanding of conspiracy ideologies. As the starting point of his research, Lenk states that the "Hochideologien" (highranking ideologies) of the eighteenth and nineteenth centuries were subjected to a decay process-especially in the twentieth century. As a result, forms of ideologies emerged which were intended to make those defects of "Hochideologien" bearable, which were becoming more and more obvious. Complementary ideologies acknowledge the contradictory and antagonistic conditions of modern societies. However, they do not legitimize these on a rational basis as the best of all possible options but deliver explanations for the unpleasant sides of capitalism. These are not blamed on capitalism as being systematically inherent to capitalist societies, but, instead, they are reduced to ontologically determined laws of human existence. This way societal conditions are indirectly affirmed because the societal defect resulting from them is withdrawn from all criticism. Religions are an example of complementary ideologies but also conservatism. They postulate value-bound ideal spheres to compensate for the real defect and, thus, serve their adherents as a kind of counseling. A concealment ideology is what Lenk defines as an imagination syndrome that may appear on its own or in concert with other ideologies. Its function is-especially in times of crisis-to distract from criticism of societal conditions by providing minority groups as objects of aggression. The antisemitism of the last third of the nineteenth century, according to Lenk, is to be understood as a form of concealment ideology: The anti-Jewish stereotypes of the "Jewish banker" or the "Jewish finance capital" conceal the socio-economic conditions of those crises. Lenk designates the last type of the

9 Cf. T. Haury, Antisemitismus von links: kommunistische Ideologie, Nationalismus und Antizionismus in der frühen DDR (Hamburg: Hamburger Edition HIS, 2002), 105-16. 
decay ideologies expression ideologies. ${ }^{10}$ The structure of expression ideologies is formed by a "conglomerate of myths"11 that, on a functional level, provides a promise of salvation in mythical communal structures, as opposed to the contradictory conditions of late capitalist societies. A rational reference within the myth conglomerate no longer exists, the emotional addressing of drive shifts is more important than the argument. Empirical data and scientific theories are only of use when they verify the mythological basic assumptions: "At this point arguing and justifying no longer takes place, but it must be believed." 12 To achieve their objective as soon as possible, expression ideologies push toward political action. They utilize, complementary to the community-myth, a Manichaean friend-enemy-thinking, ${ }^{13}$ which presets the impact direction of the actions. A (world-) conspiracy ideology, in this sense, is a (world-) conspiracy centered expression ideology.

A comparison of the structural features of antisemitism according to Haury and the conspiracy ideology following Lenk shows a high level of compliance: Personification of abstract processes of modernization, which are regarded as a global malady, Manichaeism and mythical-identitary images of collectives as promises of salvation. ${ }^{14}$ These commonalities can also be observed on the functional level. In their description of the function of antisemitism for German rightwing extremism, Rainer Erb and Michael Kohlstruck refer to Pfahl-Traughber's work for conspiracy ideologies: identity, world explanation, manipulation, and legitimization. ${ }^{15}$ Within the Manichaean worldview, antisemitism and conspiracy

10 In his studies, Lenk considered the question of whether national socialism can even be designated as an ideology. In his 1954 article Theodor W. Adorno initially refuted this due to lack of rationality and consistency but, then, in later publications did assign it this quality. See T. W. Adorno, "Beitrag zur Ideologienlehre," in Soziologische Schriften I. Gesammelte Schriften, vol. 8, ed. R. Tiedemann, (Frankfurt/Main: Suhrkamp, 1997). Lenk considered national socialism as a form of an expression ideology.

11 K. Lenk, Volk und Staat: Strukturwandel polit. Ideologien im 19. u. 20. Jahrhundert (Stuttgart: Kohlhammer, 1971), 31.

12 Ibid.

13 Cf. ibid., 143.

14 The relation to anti-Americanism also becomes apparent by means of the structural principles. As such, Tobias Jaecker identifies: dualism, projection, self-appreciation, and conspiracythinking. However, Jaecker points out that these parallels merely exist on the discursive level. In practice antisemitism is singular. Cf. T. Jaecker, Hass, Neid, Wahn: Antiamerikanismus in den deutschen Medien (Frankfurt/Main: Campus-Verlag, 2014), $363 \mathrm{f}$.

15 Cf. Pfahl-Traughber, “Bausteine'," 36-39; R. Erb and M. Kohlstruck, "Die Funktionen von Antisemitismus und Fremdenfeindschaft für die rechtsextreme Bewegung," in Strategien der extremen Rechten: Hintergründe-Analysen-Antworten, edited by S. Braun, A. Geisler, and M. Gerster (Wiesbaden: Springer Fachmedien, 2016), $244 \mathrm{f}$. 
ideologies provide an identity as oppressed fighters for all good, and by the means of personification of the "evil Jew," they are able to explain all maladies in the world and point out the guilty that need to be fought. ${ }^{16}$ Furthermore, both legitimize their own actions.

Parallels between antisemitism and conspiracy ideologies also become apparent amongst the causes, from the perspective of Critical Theory. In Elements of Antisemitism Max Horkheimer and Theodor W. Adorno invoke the concept of projection from Freudian psychoanalysis. Simplified, Freud describes projection as a defensive behavior, in which repressed individual drives are projected onto other people to be indicted. Antisemitism is ultimately defined by Horkheimer and Adorno as a "pathische Projektion" (pathological projection), which implies a projection without reflection of the Self within the object of consideration; antisemitic conspiracy ideologies and myths are a part of this process. By means of accusing Jews of world conspiracy, the desire for power and for a better life of those powerless, who experience this promise of liberalism as a lie and a mockery, becomes apparent: "instead of going into himself in order to record the protocol of the own lust for power, he [the subject] ascribes the protocols of the elders of Zion to the others." 17 In The Authoritarian Personality, the pathological projection was operationalized into quantitative and qualitative social-research as a variable of projectivity. ${ }^{18}$ In recent social-psychological research of conspiracy ideologies, it ultimately informs-independent from the explicit antisemitic items of the original study-the analysis of a conspiracy mentality, ${ }^{19}$ which is considered an individual psychological cause for conspiracy thinking. ${ }^{20}$

16 Eva Horn also identifies these three functions in her structural analysis of "conspiracy-theoretical thinking" of the nineteenth century; cf. E. Horn, "Das Gespenst der Arkana: Verschwörungsfiktion und Textstruktur der 'Protokolle der Weisen von Zion'," in Die Fiktion von der jüdischen Weltverschwörung: Zu Text und Kontext der "Protokolle der Weisen von Zion”, ed. E. Horn and M. Hagemeister (Göttingen: Wallstein, 2012), $7 \mathrm{f}$.

17 M. Horkheimer and T. W. Adorno, Dialektik der Aufklärung: Philosophische Fragmente (Frankfurt/Main: Fischer, 2003), 199.

18 Cf. T. W. Adorno et al., The Authoritarian Personality (New York: Harper \& Brothers, 1950), $239 \mathrm{f}$.

19 Cf. S. Moscovici, "The Conspiracy Mentality," in Changing Conceptions of Conspiracy, ed. C. F. Graumann and S. Moscovici (New York: Springer, 1987), 151-69.

20 Cf. Pfahl-Traughber, “'Bausteine,”; R. Imhoff and M. Bruder, "Speaking (Un-)Truth to Power: Conspiracy Mentality as a Generalised Political Attitude," European Journal of Personality 28, no. 1 (2014): 25-43; R. Imhoff, "Beyond (Right-wing) Authoritarianism: Conspiracy Mentality as an Incremental Predictor of Prejudice," in The Psychology of Conspiracy: A Festschrift for Mirosław Kofta, ed. M. Bilewicz et al. (London: Routledge, 2015), 122-41. 
One further factor is of relevance for the analysis of the relation between antisemitism and conspiracy ideologies. Since the Holocaust, new manifestations of antisemitism can be discerned which are designated "secondary" or Post-Holocaust-Antisemitism. ${ }^{21}$ Since the crime against humanity contradicts a positive identification of Antisemites as good (and German), a defense against memory and guilt takes place within this type of antisemitism that in extreme cases can result in the denial of the Holocaust-which in some countries is a criminal offense. This also occurs in combination with a perpetrator-victim reversal, for example when Jews are accused of benefitting from the Holocaust, or when Israel is compared to national socialist Germany. Because explicit antisemitic statements and actions are publicly tabooed and sanctioned, according to Werner Bergmann and Rainer Erb, a detour-communication has taken shape in which latent antisemitism is articulated in another, ostensibly non-problematic manner, for example via criticism of Israel. ${ }^{22}$ The attribute "Jewish" is purposely omitted from this communication and the single stereotypes only appear as codes and ciphers, yet, used in the certainty that the informed audience will be able to decode the intended information. ${ }^{23}$ "Anti-Jewish contents were and are (with the exception of right-wing extremist spheres) mediated as indirect acts of speech (and realized as 'detour-communication' [...]),” as Monika SchwarzFriesel and Jehuda Reinharz establish in their study of the language of Jew-Hatred in the twenty-first century. ${ }^{24}$ The antisemitic implicature must be regarded in the analysis of conspiracy-ideological statements, in order to not mistake the appearance for the essence.

Tom David Uhlig puts the findings of this paragraph in a nutshell:

Structurally the conspiracy theory is the expression of antisemitic resentments. Since the breach of civilization of the Shoah hatred toward Jews, in the so-called Western countries, can no longer be articulated in an unchanged manner, if it does not want to risk being excluded from public discourse. On the one hand, detour-communication is enclosed by information on its motives, if one follows the history of antisemitic forms of articulation. To this day many of the antisemitic images are passed on with only a few minor modifications, and can therefore easily be decoded [...]. On the other hand, the conspiracy theory reveals

21 Cf. T. W. Adorno, "Zur Bekämpfung des Antisemitismus heute," in Gesammelte Schriften, ed. R. Tiedemann (Frankfurt/Main: Suhrkamp, 1997), 20.1:360 - 83; M. Schwarz-Friesel and J. Reinharz, Die Sprache der Judenfeindschaft im 21. Jahrhundert (Berlin: De Gruyter, 2013), 26.

22 Cf. W. Bergmann and R. Erb, "Kommunikationslatenz, Moral und öffentliche Meinung: Theoretische Überlegungen zum Antisemitismus in der Bundesrepublik Deutschland," Kölner Zeitschrift für Soziologie und Sozialpsychologie 38, no. 2 (1986): 231.

23 Cf. Rensmann, Demokratie und Judenbild, 78f.; Schwarz-Friesel and Reinharz, Die Sprache der Judenfeindschaft, $37 \mathrm{f}$.

24 Schwarz-Friesel and Reinharz, Die Sprache der Judenfeindschaft, 97. 
its antisemitic descent via the function which it fulfills: the conspiracy-theoretical reductionism complies with the same societal and psychological needs, as the overt hatred towards Jews. ${ }^{25}$

In conclusion, the relation between antisemitism and conspiracy ideology seems to be so tight that a distinction appears difficult-if not even impossible. ${ }^{26}$ Antisemitism and conspiracy ideologies permeate each other reciprocally: The conspiracy ideological enables antisemitism to function as a total world explanation; ${ }^{27}$ and, by means of the Jewish enemy image, antisemitism provides conspiracy ideology with an extendable "complex stereotype-linkage," which has been passed on for centuries. ${ }^{28}$ The synthesis of both forms the myth of the "Jewish World Conspiracy."29

\section{The Myth of the "Jewish World Conspiracy"}

The emergence of the myth has been reconstructed with respect to various points. Ugo Volli notices anti-Jewish conspiracy accusations already as of the first millennium B.C.E., for example regarding the conspiracy accusations against the Israelites in Egypt which led to their exodus, or with reference to those made at the Persian court based on the biblical book Esther. ${ }^{30}$ Hannes Stein traces the origin of the myth back to the year $200 \mathrm{CE}$, to a statement made by the poet Lucius Flavius Philostratus, according to which the Jews had conspired against all humankind, what Philostratus considered verified by pointing out the isolation of the Jews. ${ }^{31}$ The reference to the myth's medieval origin is more frequent. ${ }^{32}$ To that end, the historiographical applied discourse anal-

25 Uhlig, “Abgründe der Aufklärung," 156.

26 This may be due to the fact that the first analyses of conspiracy ideologies emerged from the fields of antisemitism and right-wing extremism research (Horkheimer, Adorno) or highlighted the anti-modern ideological core.

27 Cf. Rensmann, Demokratie und Judenbild, 150.

28 Schwarz-Friesel and Reinharz, Die Sprache der Judenfeindschaft, 107.

29 Cf., e.g., E. Piper, "Achtes Bild: 'Die jüdische Weltverschwörung'," in Antisemitismus: Vorurteile und Mythen, ed. J. H. Schoeps and J. Schlör (Munich: Piper, 1996), 127-35.

30 Cf. U. Volli, "Anti-Semitism (and Now Anti-Zionism) as Prototype of Conspiracy Theory: A Theoretical and Textual Approach," Lexia: Journal of Semiotics $23-24$ (2016): 23-24.

31 Cf. H. Stein, "Hoch die Weisen von Zion!” in Verschwörungstheorien: Kursbuch, Heft 124, ed. G. S. Freyermuth and I. Karsunke (Berlin: Rowohlt, 1996), 36.

32 Cf., e.g., N. Cohn, Warrant for Genocide: The Myth of the Jewish World Conspiracy and the Protocols of the Elders of Zion (London: Serif, 1996); A. Pfahl-Traughber, Der antisemitisch-antifreimaurerische Verschwörungsmythos in der Weimarer Republik und im NS-Staat (Wien: Braumüller, 
ysis by historian Johannes Heil deserves special notice. ${ }^{33}$ He clarifies in detail that the narrative of the "Jewish World Conspiracy" did not merely originate as a consequence of modern antisemitism and The Protocols of the Elders of Zion but had already been disseminated since the thirteenth century. Jews were, besides other religiously motivated anti-Jewish stereotypes, depicted as allies of the anti-Christ during the apocalyptic end of time. Although this accusation was also made against other groups, such as the Tatars, witches, or lepers, the one against the Jews prevailed throughout the passage of centuries-even after the accusations became worldlier, due to the secularization of Christian societies, and the narratives along with the actions combined with these, began to change. The process of desacralization had, in many ways, proven problematic for the conspiracy narratives. The Christian, pre-modern apocalyptic conspiracy imagination yet beheld a historical, theological element: According to this, the end of time was immediately followed by the absolution of the Christians and the conversion of the Jews (or their extermination). Without the theological bond to the anti-Christ and apocalypse, the possibility to convert Jews, the power of the Jews limited by the anti-Christ, and the termination of the expected enslavement of the subjugated societies via divine intervention were omitted as a consequence of the process of secularization, as was also the historical-theological promise of salvation. In this context, the figure of the no longer religiously conceptualized "savior" became all the more important, who had to prevent the secular hell of eternal enslavement by the Jews. ${ }^{34}$ The conspiracy no longer necessarily led to the gateways of heaven but, instead, admonished action against the alleged conspirators, in order to evade enslavement. Furthermore, Heil notices that the desacralization of the "Jewish conspiracy" may cover the apocalyptic end of time; however, it has not left it behind itself.

Johannes Rogalla von Bieberstein thematically follows Heil's researches in his dissertation text Die These von der Verschwörung 1776-1945 (The Thesis of the Conspiracy $1776-1945){ }^{35}$ Therein the historian researches the counter-revolu-

1993), 9; Piper, “Achtes Bild,” 127; D. Pipes, Conspiracy: How the Paranoid Style Flourishes and Where it Comes From (New York: Free Press, 1997); A. Pfahl-Traughber, Antisemitismus in der deutschen Geschichte (Opladen: Leske und Budrich; VS Verlag für Sozialwissenschaften, 2002), 31; T. Jaecker, Antisemitische Verschwörungstheorien nach dem 11. September: Neue Varianten eines alten Deutungsmusters (Münster: Lit, 2005), 43; W. Wippermann, Agenten des Bösen: Verschwörungstheorien von Luther bis heute (Berlin: be.bra-Verlag, 2007), 20 - 32.

33 Cf. J. Heil, "Gottesfeinde"-“Menschenfeinde”: Die Vorstellung von jüdischer Weltverschwörung (13. bis 16. Jahrhundert) (Essen: Klartext-Verlag, 2006).

34 Cf. ibid., 536.

35 Cf. J. Rogalla von Bieberstein, Die These von der Verschwörung 1776-1945: Philosophen, Freimaurer, Juden, Liberale und Sozialisten als Verschwörer gegen die Sozialordnung (Flensburg: 
tionary conspiracy thesis in the environment of the French Revolution, which, besides philosophers, Freemasons, liberals, and socialists, also identified Jews as conspirators. Rogalla von Bieberstein refers to the socio-economic dimension of anti-Jewish hostility, which occurred as a consequence of forcing Jews into petty trade, money exchange, and lending in the Middle Ages. In this way, the Christian anti-Judaism was accompanied by a secular counterpart, and both were utilized in the counter-revolutionary conspiracy accusations against Jews. According to Rogalla von Bieberstein, Jews were initially only called "useful tools." ${ }^{36}$ However, their role would continuously solidify, with the result that soon, especially regarding the relation to Freemasonry, no distinction was made anymore, which brought about the very stable narrative of the "Judeo-Masonic World Conspiracy": United in the ostensible struggle against Christianity, promoting enlightenment within the non-French nations, supported by Jewish influence and money. ${ }^{37}$

Because "the Jews" could be displayed as symbols of modernity and they, nonetheless, due to the continuous Christian-medieval demonology, were conceived by many as beings with mysterious features, they were in a special way suited for a role in the midst of an anti-modernist and anti-liberal conspiracy-thesis. ${ }^{38}$

As of the nineteenth century, Christian counter-revolutionary positions within the world conspiracy narrative, paralleled by the rise of socialist and democratic movements, were accompanied by anti-socialist, anti-pluralist, and anti-democratic positions. ${ }^{39}$ The banking family Rothschild became a synonym for the anti-capitalist moment within the antisemitic world conspiracy narrative. ${ }^{40} \mathrm{At}$ the same time, the newspaper was established as a mass medium that, as of

Flensburger-Hefte-Verlag, 1992). Rogalla von Bieberstein's relation to Judaism must be examined critically. In the year 2002, he published the book "Jewish Bolshevism"-Myth and Reality in the "new-right" publishing house Antaios. Therein he regards the actions of those communists identified as Jews as a material foundation for "conspirator theories." However, he ignores the societal contexts of national, antisemitic formations of identity, that were decisive for the socialist and communist engagement of Jews. Cf. Rogalla von Bieberstein, "Jüdischer Bolschewismus"Mythos und Realität (Schnellroda: Ed. Antaios, 2004). Criticism on the topic by K.-P. Friedrich, review of "Jüdischer Bolschewismus": Mythos \& Realität, by Johannes Rogalla von Bieberstein Zeitschrift für Ostmitteleuropa-Forschung 52, no. 3 (2003): 425-26.

36 Rogalla von Bieberstein, Die These von der Verschwörung, 107.

37 Cf. also Pfahl-Traughber, Der antisemitisch-antifreimaurerische Verschwörungsmythos; Pipes, Conspiracy, 129-53.

38 Rogalla von Bieberstein, Die These von der Verschwörung, 114.

39 Cf. ibid., 127.

40 Cf. Piper, “Achtes Bild,” 128. 
the second half of the nineteenth century, was conceived as a "fourth power," and perceived as a threat by the conservative governments. The antisemitic stereotype of the "Jewish World Conspiracy" was solidified and extended, accordingly, by the notion of control over the media. ${ }^{41}$ Regarding the dissemination of the myth, the works of Hermann Goedsche, aka Sir John Retcliffe (1868), deserve special attention. The literary process of solidification culminated in the plagiarism of The Protocols of the Elders of Zion, first published around the turn of the nineteenth and twentieth century, of which the content was also compiled from Goedsche's antisemitic novel Biarritz. ${ }^{42}$ Regarding the global dissemination of antisemitic conspiracy myths, the Protocols play a crucial role. ${ }^{43}$ Yehuda Bauer aptly summarizes this:

The devil myth, inspired by medieval Christianity, led to another very basic antisemitic stereotype, that of the Jewish world conspiracy, translated into the infamous Protocols of the Elders of Zion at the turn of the nineteenth century. ${ }^{44}$

The Protocols serve as a starting point for the following analysis of the relation between conspiracy ideologies and antisemitism on the internet, since they are held true to be "the most significant document for propagating the myth of a Jewish world conspiracy" 45 or "an archetype or 'ideal type' of modern, 20th-century anti-Semitism." ${ }^{46}$ Ugo Volli even designates antisemitism itself a "prototypical conspiracy theory," because of its long tradition and transformability. ${ }^{47}$ On the basis of structural, functional, and historical commonalities, the question

41 Cf. ibid., 129; J. D. Seidler, Die Verschwörung der Massenmedien: Eine Kulturgeschichte vom Buchhändler-Komplott bis zur Lügenpresse (Bielefeld: transcript, 2016), 233-37.

42 For the history of origin, cf., e.g., Cohn, Warrant for Genocide; J. L. Sammons, Die Protokolle der Weisen von Zion: Die Grundlage des modernen Antisemitismus-Eine Fälschung (Göttingen: Wallstein, 1998); M. Hagemeister, "The Protocols of the Elders of Zion: Between History and Fiction,” New German Critique 35, no. 103 (2008): 83-95; W. Benz, Die Protokolle der Weisen von Zion: Die Legende von der jüdischen Weltverschwörung (Munich: Beck, 2011).

43 Cf. Pfahl-Traughber, Der antisemitisch-antifreimaurerische Verschwörungsmythos, 11, 35; Benz, Die Protokolle der Weisen von Zion, $7 \mathrm{f}$.; M. Hagemeister, "Protokolle der Weisen von Zion," in Ereignisse, Dekrete, Kontroverse, vol. 4 of Handbuch des Antisemitismus: Judenfeindschaft in Geschichte und Gegenwart, ed. W. Benz (Berlin: De Gruyter Saur, 2011), 321-25.

44 Y. Bauer, "Antisemitism and Anti-Zionism-New and Old," in Anti-Zionism and Antisemitism in the Contemporary World, ed. R. S. Wistrich (London: Palgrave Macmillan, 1990), 197.

45 Pfahl-Traughber, Der antisemitisch-antifreimaurerische Verschwörungsmythos, 11.

46 J. Heil, "Thomas of Monmouth and the Protocols of the Sages of Narbonne," in The Paranoid Apocalypse: A Hundred-Year Retrospective on The Protocols of the Elders of Zion, ed. R. Landes and S. T. Katz (New York: New York University Press, 2011), 56.

47 Volli, “Anti-Semitism,” 33. 
under consideration is whether the explicitly antisemitic Protocols-taking into account the concept of detour-communication-are indeed "the prototype of all world conspiracy theories." ${ }^{48}$ Chip Berlet refers to such conspiracy ideologies as "analogs," 49 that he on the one hand distinguishes into explicit antisemitic conspiracy ideologies, which structurally replicate the Protocols without explicitly mentioning them, and on the other hand into ostensibly non-antisemitic conspiracy ideologies that operate with codes (e.g., "Rothschild," "Zionists"). Regarding the USA in the year 2012, Berlet notices that the most frequent conspiracy ideologies mention other world conspirators, without consciously or overtly mentioning Jews. ${ }^{50}$

\section{Antisemitism and post-Holocaust Conspiracy Ideologies on Facebook}

The study is restricted to the "supply-side" 51 of conspiracy ideologies on the internet. The focus is on posts by certain Facebook pages, not on comments by users or page administrators/moderators. This medium has led to a democratization of the means of communication of modern societies, especially since the expansion of publishing possibilities for general users. Also, those discourses ex-

48 W. Benz, "Die mächtigste aller Lügen,” ZEIT Geschichte, October 24, 2017, http://www.zeit. de/zeit-geschichte/2017/03/protokolle-weisen-zion-antisemitismus-faelschung/komplettansicht. However, the questions, if the Protocols constituted a warrant for genocide, and if the content of the Protocols were only interpreted as antisemitic because of their paratexts and therefore merely a "pure projection surface," shall not be considered at this point. For the debate on the link of the Protocols and Holocaust see Cohn, Warrant for Genocide; M. Kuzmick, "Protocols of the Elders of Zion," in Conspiracy Theories in American History: An Encyclopedia, ed. P. Knight (Santa Barbara: ABC-CLIO, 2003), 595-97; critical perspectives on the other hand by R. S. Levy, "Die ‘Protokolle der Weisen von Zion' und ihre Entlarvung: Ein vergebliches Unterfangen?” in Die Fiktion von der jüdischen Weltverschwörung: $Z u$ Text und Kontext der "Protokolle der Weisen von Zion”, ed. E. Horn and M. Hagemeister (Göttingen: Wallstein, 2012), 208-30. As an argument for the pure projection surface, see E. Horn, "Das Gespenst der Arkana: Verschwörungsfiktion und Textstruktur der 'Protokolle der Weisen von Zion'," in Die Fiktion von der jüdischen Weltverschwörung: Zu Text und Kontext der 'Protokolle der Weisen von Zion,' ed. E. Horn and M. Hagemeister (Göttingen: Wallstein, 2012), 1-25.

49 The term was originally used by Stephen Eric Bronner. Cf. C. Berlet, "Protocols to the Left, Protocols to the Right: Conspiracism in American Political Discourse at the Turn of the Second Millennium," in The Paranoid Apocalypse: A Hundred-Year Retrospective on The Protocols of the Elders of Zion, ed. R. Landes and S. T. Katz (New York: New York University Press, 2011), 189. 50 Cf. ibid., $189 \mathrm{f}$.

51 Rensmann, Demokratie und Judenbild, 78. 
cluded in the past due to quality standards became publicly discernable via the internet. Social media (Facebook, YouTube, Twitter, etc.) that enabled individuals to informally organize and connect themselves based on their interests also contributed to this development. With respect to antisemitism and conspiracy ideologies, this means that the internet in general, and social media, in particular, provides a space that resists a reflection process of their own ideological and/ or delusional worldview but instead enforces these worldviews reciprocally. As Mark Weitzman described these processes at the beginning of this century:

A single extremist, who had up until now been isolated, can now connect with similar minded people, in different locations, and thus create the empowering illusion that their movement is indeed international and growing. ${ }^{52}$

In order to answer the questions of whether the Protocols are still present on the internet as "analogs," and how the relation to antisemitism is expressed in these, a qualitative analysis of postings of German language Facebook pages which are assigned to the conspiracy-ideological milieu was conducted. For one thing, this examination intended to establish whether the mediated content constitutes "analogs," and furthermore determine whether antisemitism is explicitly or implicitly implied, or not at all. To operationalize the "analogs," Chip Berlet's compiled accusations against the Jews from the Protocols was used, which can be expressed explicitly, however, without referring to the Protocols, or implicitly via codes. Because single Facebook posts do not reach the scope of the Protocols, the accusations compiled by Berlet are conceptualized as "analog"-elements:

1. Conspirators/Jews are behind a plan for global conquest.

2. Conspirators/Jews work through Masonic lodges.

3. Conspirators/Jews use liberalism to weaken church and state.

4. Conspirators/Jews control the press.

5. Conspirators/Jews work through radicals and revolutionaries.

6. Conspirators/Jews manipulate the economy, especially through banking monopolies and the power of gold.

7. Conspirators/Jews encourage issuing paper currency not tied to the gold standard.

8. Conspirators/Jews promote financial speculation and use of credit.

52 M. Weitzman, “The Internet is our Sword': Aspects of Online Antisemitism," in Remembering for the Future: The Holocaust in an Age of Genocide, ed. J. K. Roth and E. Maxwell (New York: Palgrave, 2001), 921. 
9. Conspirators/Jews replace traditional educational curriculum to discourage independent thinking.

10. Conspirators/Jews encourage immorality among Christian youth.

11. Conspirators/Jews use intellectuals to confuse people.

12. Conspirators/Jews control "puppet" governments both through secret allies and by blackmailing elected officials.

13. Conspirators/Jews weaken laws through liberal interpretations.

14. Conspirators/Jews will suspend civil liberties during an emergency and then make the measures permanent. ${ }^{53}$

The Facebook pages were selected based on the bachelor's thesis of Josef Holnburger and Andreas Hartkamp from 2017. In this work, they analyze the network and user behavior of 84 conspiracy-ideological Facebook pages that have over 5000 Likes at their disposal in the German-speaking area. The pages were categorized as conspiracy-ideological due to the fact that in their posts, they disseminated the narrative of a secret conspiracy of a small elite, aiming to attain power and to disclose this conspiracy concealed by lies and propaganda. ${ }^{54}$ Within the scope of the following research, a sample of 200 postings was examined, consisting of the respective twenty posts with the highest level of reader engagement, on the ten most far-reaching German-language conspiracy-ideological Facebook pages during the time period from January 1, until June 30, 2017. ${ }^{55}$ The engagement was measured based on the sum of likes, comments, likes of comments, and shares. The data was aggregated and extracted with the tool Net$v i z z{ }^{56}$ to subsequently be processed by means of the software for qualitative data-analysis, MAXQDA.

53 Cf. Berlet, "Protocols to the Left," 188.

54 Cf. J. Holnburger and A. Hartkamp, "Verschwörungstheorien und soziale Netzwerke: Gegenöffentlichkeit 2.0?” (BA thesis, University of Hamburg, 2017), 33-37.

55 The analyzed Facebook pages are Killuminati, KenFM, RT Deutsch (Russia Today German), Freie Medien (Free Media, not publicly accessible any more after November 2017), Zentrum der Gesundheit (Center for Health), Der Wächter (The Guardian), Gegen den Strom (Countercurrent), Anti BILD, Frieden rockt (peace rocks) and Christoph Hörstel (leader of a German conspiracy ideologically party, Neue Mitte/New Center). Since the page Zentrum der Gesundheit posted no content except links to their website, the eleventh Facebook page from the Holnburger/Hartkamp ranking, COMPACT-Magazin (deplatformed in 2020), had been added additionally.

56 Cf. B. Rieder, “Studying Facebook via Data Extraction: The Netvizz Application,” WebSci' 13 (2013): http://thepoliticsofsystems.net/permafiles/rieder_websci.pdf. 


\section{Analysis}

On the basis of their immediate Facebook content (post, picture/meme, video, article-link-preview) the 200 posts were assigned to operationalized codes which were drawn from the match with Chip Berlet's "analogs"-elements. A subsequent examination should, then, determine if the elements of the "analogs" in the single posts exhibit an explicit, implicit, or even no antisemitic reference at all.

It can be ascertained that on the formal level, the posts within the examined samples contain various different text content, links, pictures/memes, and videos in different combinations, created specifically for Facebook. The links refer to different Facebook pages, YouTube, their own website, or certain articles of the "mainstream media," to underline their own statements. Posts on the Facebook pages RT Deutsch and COMPACT-Magazin, in most cases, share links to their own website and publish pieces of the linked text as post content with a minimum of modifications made. The length of the posts varies by comparison of the different pages but also within the individual pages. It ranges from one post with a linked meme, which consists solely of one emoticon, to long posts with several paragraphs and additional links. In cases of short posts, for the most part, an affirmative reference to the shared content (picture/meme, video) can be established, which can immediately be consumed on the Facebook pages.

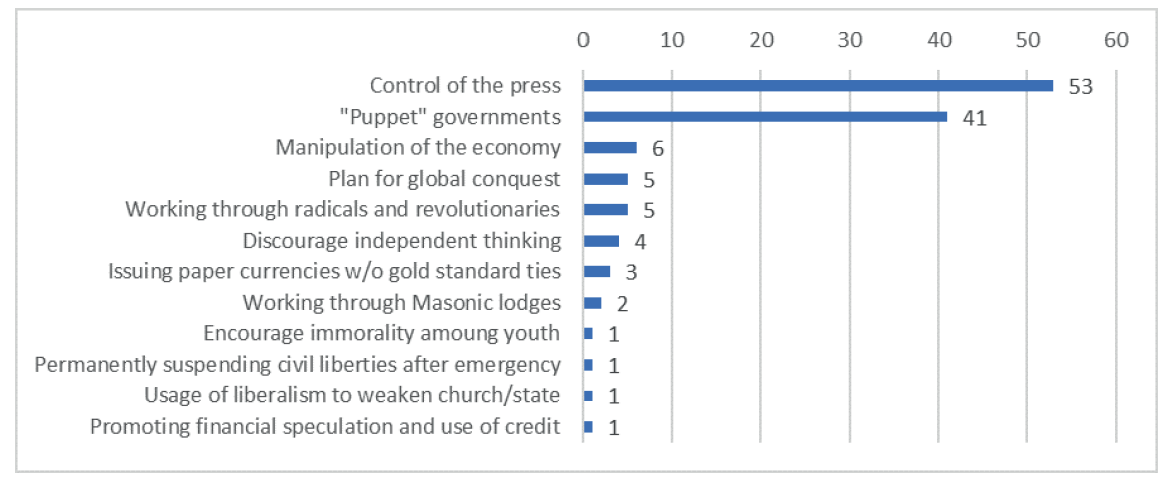

Fig. 1: Frequency of “Analog”-Elements in Number of Postings

In 78 posts (39\%) of the examined sample, a total of 123 uses of "analog"elements could be determined. As illustrated in the image above, the accusations that were made most frequently within these were Conspirators/Jews control the 
press and Conspirators/Jews control "puppet" governments both through secret allies and by blackmailing elected officials. ${ }^{57}$ On that note the Facebook page Frieden rockt (peace rocks) ended almost all posts, inter alia, with this addition:

Our principle: Education and knowledge should always be accessible to everyone. Today, more than ever, it is important to form one's own opinion and to not simply let the media take over this task! Discover further exciting articles \& videos on our website [...] (e. g., Frieden rockt, May 7, 2017, 5:21 pm)

The control of the government is expressed in simple posts,

"Don’t let yourselves be manipulated by the hypocritical politicians!!!" [...]

(Anti Bild, March 14, 2017, 10:52pm)

but can also be formulated in a more complex manner:

Qatar threatened by its neighbors! Crisis intensifying!! [...] The incredible conditions laid down by the dear Arabic brothers amount to an incapacitation of the government, Qatar would practically lose its sovereignty, these conditions are PURPOSEFULLY designed unacceptably! And if Qatar accepts the conditions THE WAR WILL COME ANYWAY! Because Washington wants to have Iran attacked! Hopefully, Russia and China will get involvedand pledge assistance to Doha. That is the only way to stabilize the situation! Setting the globe on fire must become expensive for Washington.

(Christoph Hörstel, June 23, 2017, 10:17 pm)

Furthermore, it can be established that most of the posts with "analog"-elements (72 posts; 92\%) do not exhibit direct antisemitic content, as is the case with the examples already mentioned. ${ }^{58}$ No post of the examined Facebook pages exhibits explicit antisemitism. Within the posts, antisemitism is expressed implicitly via codes (6 posts; $8 \%$ ). Evidence of antisemitism was provided on the basis of the entire content of posts as antisemitic references are not, in every case, directly oriented toward the "analog"-elements. Stereotypes and codes are not exclusively placed within the post but in some cases expressed within the linked videos or pictures/memes. In four cases, Jewish names (Rothschild, George Soros) were used as antisemitic codes in combination with antisemitic stereo-

57 Only the accusation "Conspirators/Jews encourage issuing paper currency not tied to the gold standard" has experienced modernization that is now directed against the abolition of cash, in favor of electronic means of payment.

58 These posts, accordingly, exhibit conspiracy-ideological narratives, which either vaguely state the allegation of manipulation of politics and media, pretend to be critical of capitalism, or, in essence, are anti-American or positioned against "the West." 
types to describe conspirators. For example, to point out the alleged Jewish influence on French politics:

Macron before election victory: Bankster-candidate from out of nowhere Unbelievable; the French example shows at what point we have arrived: A former financier of the Rothschildarea becomes the minister of finance - and then takes over the presidential election because all of the cartel-media like him - as ordered by their masters. THAT is the condition of democracy in Europe today. Macron is a disease symptom - no more and no less, his election victory seals our fate. [...]

(Christoph Hörstel, May 4, 2017, 6:39 pm)

In another case, a video montage of two interviews with German cabaret artists concerning the topic of censorship by the media was posted. As a cabaret artist speaks of "Rotstift" (red pen) in order to express censorship, a picture of Jacob Rothschild with the logo "Rotschild [sic]" is inserted into the video for a few seconds..$^{59}$

The concluding two cases contain implicit antisemitism. The first case concerns the use of the caricature "Gangsters" by the antisemitic illustrator David Dees, in a video that criticizes Barack Obama's politics and that, inter alia, depicts Alan Greenspan as part of the money- and interest-critical FED-conspira$\mathrm{cy}{ }^{60}$ The second case is a post that refers positively to the antisemitically connotated accusation of the former chairman of the Social Democratic Party of Germany (SPD), Martin Schulz, implying that Israel deprives the Palestinians of water: ${ }^{61}$

[...] Unlike Merkel and Gabriel Martin Schulz also has positive sides. For instance, his agency against unchecked per diems, and also his criticism of Israel's water-distribution. [...] (Gegen den Strom, January 27, 2017, 8:40pm)

\section{“Analog"-Elements and Antisemitism}

The special feature of the implicitly antisemitic posts is not portrayed by its quantity but can be illustrated by its position within the overall context. In

59 Cf. Frieden rockt, April 3, 2017, 2:32pm, Min 03:11.

60 Cf. Gegen den Strom, January 23, 2017, 10:34pm. For the original, cf. D. Dees, The Political Art of David Dees: Volume One, 2006-2013 (Leipzig: Der Schelm, 2016), 88.

61 On Schulz's remarks, cf. M. Newman, "Netanyahu: EU Parliament Head Has 'Selective Hearing," The Times of Israel, February 12, 2014, https://www.timesofisrael.com/netanyahu-eu-par liament-head-has-selective-hearing/. 
line with the function of perception, they operate as the highest conspiracy-ideological category. On a small scale, this can be demonstrated within a post, and, on a large scale, by linking posts to an all-encompassing ideological world-explanatory system. Very extensive posts, in particular, be they text or video, use antisemitic codes in this way. In such a manner, a longer post initially deals with the end of the $500 €$ note thematically:

[...] Does organized crime really need the 500 Euro-note? Every child knows that this is not the case. It also knows that multi-billions that are scammed in an organized manner end up on the accounts of the large providers of financial services. It is the bank money, the digital money, that is used to commit the large capital crimes today.

Money rules the world but who rules the money?

'Give me the control over the currency of a nation, then it doesn't matter to me who makes the laws.' - Mayer Amschel Rothschild. [...]

(KenFM, January 26, 2017, 8:50pm)

First of all, the "analog"-element Conspirators/Jews encourage issuing paper currency not tied to the gold standard is used in its modernized form in order to draw attention to the quote assigned to Mayer Amschel Rothschild (Conspirators/Jews control "puppet" governments both through secret allies and by blackmailing elected officials) via the systematical integrating of the accusation of having control over money (Conspirators/Jews manipulate the economy, especially through banking monopolies and the power of gold).

The systematical connection through several posts of the page is revealed by the following example. The Facebook page "Christoph Hörstel” initially describes the media as being controlled by a cartel,

HYPE over the SPD-candidate for the chancellorship?!?--sure: in cartel-media!

(Christoph Hörstel, April 12, 2017, 7:02pm)

which, in another post, was already determined as a cartel of banks:

'All banks worldwide form ONE cartel.' Quick: Who said that?-The Left?-Hörstel?-University study (answer below) Fact is: One who doesn't want to reform our interest- and tuitionsystem, cannot bring anything new into the world. [...]

(Christoph Hörstel, April 5, 2017 10:54 pm)

As the force behind the banks, the page ultimately presents the "Rothschildarea," as already quoted above.

This analysis was restricted to the use of "analog"-elements by certain Facebook pages within a certain time period. However, it is to be expected that the function of perception also proves to be efficient beyond the analyzed area. 
The pages link to a network of other pages and platforms where antisemitism need not be expressed implicitly. Websites or videos that disseminate the myth of the "Jewish World Conspiracy" can be reached with only a few clicks.

The function of world explanation of antisemitism can also be activated in another way. Decoding of the antisemitic potential of a post by users on Facebook in the comments is an aspect that was not illuminated in this study. Further studies are necessary to trace the decoding process on the side of the recipients. On that note, two users made the following comments under an article of Compact Magazin in which George Soros was called the "puppet master behind various colorful revolutions" in an article-preview: ${ }^{62}$

Rockefeller and Rothschild also need to be disposed of.

(February 21, 2017, 4:43pm)

Those are but two of the many others that also need to be disposed of. Those two mentioned are merely the most prominent.

(February 21, 2017, 10:09pm)

\section{Conclusion}

As pointed out, a structural and a functional correlation exists between antisemitism and conspiracy ideologies. Under consideration of the possibility of detourcommunication, the short qualitative study illustrates how conspiracy-ideological content-regarding the "analog"-elements of the Protocols or not-can be traced back to the old myth of the "Jewish World Conspiracy" via antisemitic codes. The passed on stock of knowledge of the myth facilitates the implementation of "Jews" as the highest category of knowledge within conspiracy-ideological contexts.

However, the result of the study merely illuminates one aspect of the correlation between antisemitism and conspiracy ideologies-that of the explanation of the world. This can be considered a starting point for further research. A further analysis of those identity constructions inherent to the posts but also and especially to the comments would greatly promote the state of knowledge, regarding, for example, the expression of guilt- and memory-resistance by trivialization of national socialism in the context of conspiracy ideologies. One example made this clear:

62 COMPACT-Magazin, February 21, 2017, 3:55 pm. 
The largest pharma-conspiracy of all times is uncovered. [...] Rockefeller discredited all medicine by prohibiting colloidal silver (nano-silver) with unjust methods. [...] Hence, every year millions of human beings die because of Rockefeller who murders more human beings in just one year than Hitler did during the entire Second World War.

(Freie Medien, February 16, 2017, 08:00 am; post no longer publicly accessible since November 2017)

Finally, we can conclude that the Protocols, as "analogs" are still relevant for conspiracy-ideological discourses. On this matter Deborah Lipstadt's assessments are also valid for the German context, especially regarding the international internet-based network of the milieu:

In truth, with the growth of the Internet, it is difficult and somewhat anachronistic to speak of national borders. The words of an imam in Cairo or a preacher in Idaho can be heard in real time in Dearborn or Dubai, as well as in an array of other places. [...] I would argue that, while the conspiracy theories promulgated by the Protocols have had but a limited impact in the United States, we who worry about such things must remain alert not so much for the Protocols itself as for what Chip Berlet calls their analogs. It is too easy for people to have their weltanschauung colored by these myths. ${ }^{63}$

Jan Rathje is co-founder of the Center for Monitoring, Analysis and Strategy in Berlin. His research interests are right-wing extremism, antisemitism, conspiracy ideologies, and sovereigntist movements. He has published on all of these research areas.

\section{References}

Adorno, Theodor W. "Beitrag zur Ideologienlehre." In Soziologische Schriften I. Gesammelte Schriften, edited by Rolf Tiedemann, 8:457-77. Frankfurt/Main: Suhrkamp, 1997.

Adorno, Theodor W. "Zur Bekämpfung des Antisemitismus heute." In Gesammelte Schriften, edited by Rolf Tiedemann, 20.1:360 - 83. Frankfurt/Main: Suhrkamp, 1997.

Adorno, Theodor W., Else Frenkel-Brunswik, Daniel J. Levinson, and R. Nevitt Sanford. The Authoritarian Personality. New York: Harper \& Brothers, 1950.

Bauer, Yehuda. "Antisemitism and Anti-Zionism-New and Old." In Anti-Zionism and Antisemitism in the Contemporary World, edited by Robert S. Wistrich, 195-207. London: Palgrave Macmillan, 1990.

63 D. Lipstadt, "The Protocols of the Elders of Zion on the Contemporary American Scene: Historical Artifact or Current Threat?" in The Paranoid Apocalypse: A Hundred-Year Retrospective on The Protocols of the Elders of Zion, ed. R. Landes and S. T. Katz (New York: New York University Press, 2011), 183. 
Bayer, Lili and Larry Cohler-Esses. "Evil Soros: Dog Whistling Anti-Semitism in Viktor Orbán's Hungary." Forward, May 30, 2017. https://forward.com/news/world/373162/evil-sorosdog-whistling-anti-semitism-in-viktor-orbans-hungary/.

Benz, Wolfgang. “Die mächtigste aller Lügen.” ZEIT Geschichte, October 24, 2017. http://www. zeit.de/zeit-geschichte/2017/03/protokolle-weisen-zion-antisemitismus-faelschung/kom plettansicht.

Benz, Wolfgang. Die Protokolle der Weisen von Zion: Die Legende von der jüdischen Weltverschwörung. Munich: Beck, 2011.

Bergmann, Werner, and Rainer Erb. "Kommunikationslatenz, Moral und öffentliche Meinung: Theoretische Überlegungen zum Antisemitismus in der Bundesrepublik Deutschland.” Kölner Zeitschrift für Soziologie und Sozialpsychologie 38, no. 2 (1986): 223-46.

Berlet, Chip. "Protocols to the Left, Protocols to the Right: Conspiracism in American Political Discourse at the Turn of the Second Millennium." In The Paranoid Apocalypse: A Hundred-Year Retrospective on The Protocols of the Elders of Zion, edited by Richard Landes and Steven T. Katz, 186-218. New York: New York University Press, 2011.

Cohen, Richard. "Trump Clings to Conspiracy Theories-and Strengthens the Case for his Removal.” The Washington Post, November 29, 2017. https://www.washingtonpost.com/ blogs/post-partisan/wp/2017/11/29/trump-clings-to-conspiracy-theories-and-strength ens-the-case-for-his-removal/.

Cohn, Norman. Warrant for Genocide: The Myth of the Jewish World Conspiracy and the Protocols of the Elders of Zion. London: Serif, 1996.

Dees, David. The Political Art of David Dees: Volume One, 2006-2013. Leipzig: Der Schelm, 2016.

Erb, Rainer, and Michael Kohlstruck. "Die Funktionen von Antisemitismus und Fremdenfeindschaft für die rechtsextreme Bewegung." In Strategien der extremen Rechten: Hintergründe-Analysen-Antworten, edited by Stephan Braun, Alexander Geisler, and Martin Gerster, 229-56. Wiesbaden: Springer Fachmedien, 2016.

Friedrich, Klaus-Peter. Review of "Jüdischer Bolschewismus": Mythos \& Realität, by Johannes Rogalla von Bieberstein. Zeitschrift für Ostmitteleuropa-Forschung 52, no. 3 (2003): 425-26.

Hagemeister, Michael. "The Protocols of the Elders of Zion: Between History and Fiction." New German Critique 35, no. 103 (2008): 83-95.

Hagemeister, Michael. "Protokolle der Weisen von Zion.” In Ereignisse, Dekrete, Kontroverse, vol. 4 of Handbuch des Antisemitismus: Judenfeindschaft in Geschichte und Gegenwart, edited by Wolfgang Benz, 321-25. Berlin: De Gruyter Saur, 2011.

Haury, Thomas. Antisemitismus von links: kommunistische Ideologie, Nationalismus und Antizionismus in der frühen DDR. Hamburg: Hamburger Edition HIS, 2002.

Heil, Johannes. "Gottesfeinde”-“Menschenfeinde”: Die Vorstellung von jüdischer Weltverschwörung (13. bis 16. Jahrhundert). Essen: Klartext-Verlag, 2006.

Heil, Johannes. "Thomas of Monmouth and the Protocols of the Sages of Narbonne." In The Paranoid Apocalypse: A Hundred-Year Retrospective on The Protocols of the Elders of Zion, edited by Richard Landes and Steven T. Katz, 56-78. New York: New York University Press, 2011.

Holnburger, Josef, and Andreas Hartkamp. "Verschwörungstheorien und soziale Netzwerke: Gegenöffentlichkeit 2.0?” BA thesis, University of Hamburg, 2017. 
Horkheimer, Max, and Theodor W. Adorno. Dialektik der Aufklärung: Philosophische Fragmente. Frankfurt/Main: Fischer, 2003.

Horn, Eva. "Das Gespenst der Arkana: Verschwörungsfiktion und Textstruktur der 'Protokolle der Weisen von Zion'." In Die Fiktion von der jüdischen Weltverschwörung: Zu Text und Kontext der 'Protokolle der Weisen von Zion,' edited by Eva Horn and Michael Hagemeister, 1-25. Göttingen: Wallstein, 2012.

Imhoff, Roland. "Beyond (Right-wing) Authoritarianism: Conspiracy Mentality as an Incremental Predictor of Prejudice." In The Psychology of Conspiracy: A Festschrift for Mirostaw Kofta, edited by Michal Bilewicz, Aleksandra Cichocka, and Wiktor Soral, 122 - 41. London: Routledge, 2015.

Imhoff, Roland, and Martin Bruder. "Speaking (Un-)Truth to Power: Conspiracy Mentality as a Generalised Political Attitude.” European Journal of Personality 28, no. 1 (2014): 25-43.

Jaecker, Tobias. Antisemitische Verschwörungstheorien nach dem 11. September: Neue Varianten eines alten Deutungsmusters. Münster: Lit, 2005.

Jaecker, Tobias. Hass, Neid, Wahn: Antiamerikanismus in den deutschen Medien. Frankfurt/Main: Campus-Verlag, 2014.

Kuzmick, Marlon. "Protocols of the Elders of Zion." In Conspiracy Theories in American History: An Encyclopedia, edited by Peter Knight, 595-97. Santa Barbara: ABC-CLIO, 2003.

Lenk, Kurt. Volk und Staat: Strukturwandel polit. Ideologien im 19. u. 20. Jahrhundert. Stuttgart: Kohlhammer, 1971.

Levy, Richard S. “Die 'Protokolle der Weisen von Zion' und ihre Entlarvung: Ein vergebliches Unterfangen?" In Die Fiktion von der jüdischen Weltverschwörung: Zu Text und Kontext der "Protokolle der Weisen von Zion", edited by Eva Horn and Michael Hagemeister, 208-30. Göttingen: Wallstein, 2012.

Lipstadt, Deborah. "The Protocols of the Elders of Zion on the Contemporary American Scene: Historical Artifact or Current Threat?" In The Paranoid Apocalypse: A Hundred-Year Retrospective on The Protocols of the Elders of Zion, edited by Richard Landes and Steven T. Katz, 172-85. New York: New York University Press, 2011.

Moscovici, Serge. "The Conspiracy Mentality." In Changing Conceptions of Conspiracy, edited by Carl F. Graumann and Serge Moscovici, 151-69. New York: Springer, 1987.

Munnes, Stefan, Nora Lege, and Corinna Harsch. "Zum Antisemitismus in der neuen Friedensbewegung: Eine Weltanschauungsanalyse der ersten bundesweiten Mahnwachen für den Frieden." In Jahrbuch für Antisemitismusforschung 25, edited by Stefanie Schüler-Springorum, 217-40. Berlin: Metropol-Verlag, 2016.

Newman, Marissa. "Netanyahu: EU Parliament Head Has 'Selective Hearing'." The Times of Israel, February 12, 2014. https://www.timesofisrael.com/netanyahu-eu-parliament-headhas-selective-hearing/.

Pfahl-Traughber, Armin. Antisemitismus in der deutschen Geschichte. Opladen: Leske und Budrich; VS Verlag für Sozialwissenschaften, 2002.

Pfahl-Traughber, Armin. Der antisemitisch-antifreimaurerische Verschwörungsmythos in der Weimarer Republik und im NS-Staat. Wien: Braumüller, 1993.

Pfahl-Traughber, Armin. “'Bausteine’ zu einer Theorie über 'Verschwörungstheorien': Definitionen, Erscheinungsformen, Funktionen und Ursachen." In Verschwörungstheorien: Theorie-Geschichte-Wirkung, edited by Helmut Reinalter, 30-44. Innsbruck: Studien-Verlag, 2002. 
Piper, Ernst. “Achtes Bild: 'Die jüdische Weltverschwörung'.” In Antisemitismus: Vorurteile und Mythen, edited by Julius H. Schoeps and Joachim Schlör, 127-35. Munich: Piper, 1996.

Pipes, Daniel. Conspiracy: How the Paranoid Style Flourishes and Where it Comes From. New York: Free Press, 1997.

Rensmann, Lars. Demokratie und Judenbild: Antisemitismus in der politischen Kultur der Bundesrepublik Deutschland. Wiesbaden: VS Verlag für Sozialwissenschaften, 2005.

Rieder, Bernhard. "Studying Facebook via Data Extraction: The Netvizz Application." WebSci' 13 (2013): http://thepoliticsofsystems.net/permafiles/rieder_websci.pdf.

Rogalla von Bieberstein, Johannes. "Jüdischer Bolschewismus"-Mythos und Realität. Schnellroda: Ed. Antaios, 2004.

Rogalla von Bieberstein, Johannes. Die These von der Verschwörung 1776-1945: Philosophen, Freimaurer, Juden, Liberale und Sozialisten als Verschwörer gegen die Sozialordnung. Flensburg: Flensburger-Hefte-Verlag, 1992.

Salzborn, Samuel. 'Vom rechten Wahn: 'Lügenpresse,' 'USrael,' 'Die da oben' und 'Überfremdung'." In Stolz und Vorurteile, edited by Martin Bauer, Karsten Malowitz, and Stefan Mörchen. Mittelweg 36: Zeitschrift des Hamburger Instituts für Sozialforschung 6 (2016/2017): 76-96.

Sammons, Jeffrey L. Die Protokolle der Weisen von Zion: Die Grundlage des modernen Antisemitismus-Eine Fälschung. Göttingen: Wallstein, 1998.

Schwarz-Friesel, Monika, and Jehuda Reinharz. Die Sprache der Judenfeindschaft im 21. Jahrhundert. Berlin: De Gruyter, 2013.

Seidler, John David. Die Verschwörung der Massenmedien: Eine Kulturgeschichte vom Buchhändler-Komplott bis zur Lügenpresse. Bielefeld: transcript, 2016.

Stein, Hannes. “Hoch die Weisen von Zion!” In Verschwörungstheorien: Kursbuch, Heft 124, edited by Gundolf S. Freyermuth and Ingrid Karsunke, 35-48. Berlin: Rowohlt, 1996.

Uhlig, Tom D. "Abgründe der Aufklärung: Über Verschwörungstheorien als antisemitisches Zerrbild der Ideologiekritik." In Populismus, Paranoia, Pogrom: Affekterbschaften des Nationalsozialismus, edited by Kurt Grünberg, Wolfgang Leuschner, and Initiative 9. November, 155-72. Frankfurt/Main: Brandes \& Apsel, 2017.

Volli, Ugo. "Anti-Semitism (and Now Anti-Zionism) as Prototype of Conspiracy Theory: A Theoretical and Textual Approach." Lexia: Journal of Semiotics $23-24$ (2016): 19-34.

Weitzman, Mark. “'The Internet is our Sword': Aspects of Online Antisemitism.” In Remembering for the Future: The Holocaust in an Age of Genocide, edited by John K. Roth and Elisabeth Maxwell, 911-25. New York: Palgrave, 2001.

Wetzel, Juliane. "Verschwörungstheorien." In Begriffe, Theorien, Ideologien, vol. 3 of Handbuch des Antisemitismus: Judenfeindschaft in Geschichte und Gegenwart, edited by Wolfgang Benz, 334-37. Berlin: De Gruyter Saur, 2010.

Wippermann, Wolfgang. Agenten des Bösen: Verschwörungstheorien von Luther bis heute. Berlin: be.bra-Verlag, 2007. 